\title{
Study on the Curriculum Construction of Digital Media Art Major
}

\author{
Yongqiong Zhu \\ School of Wuhan Business University, Wuhan 430056, China. \\ zyqzhuyongqiong@126.com
}

Keywords: digital media art, curriculum system, talent cultivation.

\begin{abstract}
Digital media art is a new art category combining technology and art. It mainly studies and explores new art forms mainly based on technology. With the high development and integration of computer technology, network technology, digital communication and other technologies, how to construct the curriculum system of digital media art to adapt to the development of The Times is the core issue that digital media art majors need to consider. Based on the national standard of teaching quality of digital media specialty, this paper constructs a curriculum system with film and television special effects technology, 3d game technology and human-computer interaction as the teaching objectives. The research of this paper can improve the teaching effect of digital media art major and the creative ability of college students.
\end{abstract}

\section{Introduction}

With rapid development of multimedia, film and television industry and surrounding digital media industry, cultural media enterprises are springing up, and the relationship between supply and demand of talents in the industry has undergone great changes. New media constantly launching an offensive against traditional media that accelerate the process of media industrialization and marketization, as well as the rapid growth of emerging media, which all promote the demand of the whole media industry for cross-disciplinary talents who know both art and technology to rise linearly, and the requirements for talents' professional experience are also increasingly high.CG technology, digital film and television design and production, virtual reality, game research and development talent is becoming one of the biggest market demand and future shortage of talent, become a bottleneck restricting the development of the media industry. In such an environment, how to train talents who are connected with new media technology in today's art education, so that they can be in line with the industrial structure in the future and make great achievements in the future cultural market is a topic that higher art education must meet. In 2001, digital media art came into being.

Digital media art is centered on CG technology and art, based on the broadband Internet, digital high-definition applications, for audio technology, network multimedia art, digital art, television, film and television production, electronic publishing, digital art, and many other disciplines. It is engaged in the teaching and research of the edge and cross, and is committed to cultivating the composite technical application art talents with solid artistic theory foundation and mastering digital 
technology skills.Since Communication University of China took the lead in setting up digital media art major in 2001, by the autumn of 2018, more than 100 colleges and universities have set up "digital media art" major, which can only alleviate the shortage of digital media art talents in China in the short term and restrict the development of China's cultural industry and economy. Therefore, the establishment of digital media art majors for China's economic development and cultural construction has important significance.

\section{Construction of digital media art curriculum system}

\subsection{Law of talent cultivation for digital media art major}

According to National Standard Digital media professional Teaching Quality, the digital media art professional talents training target for training master, film and television post-production of film and television special effects, video production, product development, the Internet network interaction design and related tools application of basic knowledge, basic theory and method, can in the related fields of media and cultural industries engaged in film and television, network, media planning, creation, production, transmission, operation or management of innovative talents.

Through the analysis of the training objectives of this major, the author concludes that the training rules of digital media art professionals mainly include the following points:

1) Requires both art and technology: digital media art is a cross discipline, unable to comply with and follow the traditional artistic style, and in the process of using digital technology to create, for practitioner, not only has the skilled operation skills, also need to have good artistic accomplishment, is a kind of art and technology of talents training.

2) Innovation: in the field of art, innovation is the basic requirement for artistic talents. Only with the characteristics of independent thinking, creation can be full of new ideas, unique characteristics.

3) Teamwork spirit is required: In the drama and film production process, complex professional technical operation and operation are required. Especially in some large-scale digital media art creations, it is difficult to rely solely on individual work and efforts, and teamwork is required. Communication and coordination between team members are very important in the process of technical operation. It is difficult to complete creative tasks without teamwork spirit, so the cultivation of digital media art talents needs to pay attention to the cultivation of teamwork spirit.

\subsection{Construction of course system of digital media art major}

Aiming at the training objective of digital media art talents, the curriculum system of digital media art is designed as shown in the figure1

The curriculum system is mainly composed of general education, subject basis education, professional education, practical teaching, quality development and innovation and entrepreneurship education course units. The general education education course unit mainly includes knowledge related to humanities and social sciences, science and technology and career planning.Education unit mainly includes basic courses of art.Education course unit is mainly composed of compulsory course unit and elective course unit.The practical teaching unit includes curriculum practice, cognitive practice, graduation practice and graduation design, etc.Quality development and innovation and entrepreneurship education includes innovation and entrepreneurship and social practice.

The core courses set according to the curriculum system are shown in the figure 2: 


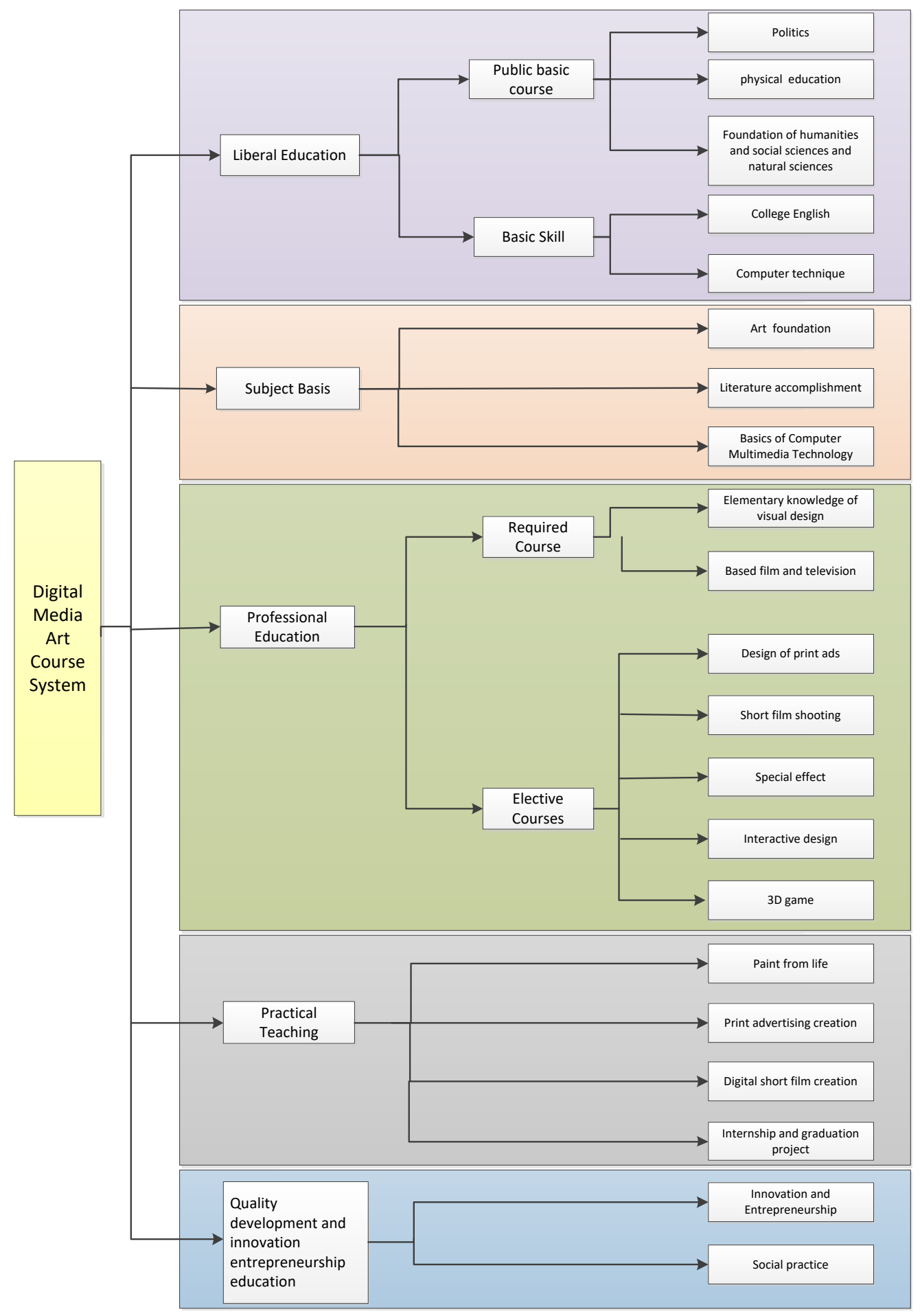

Fig. 1 Curriculum system of digital media art 

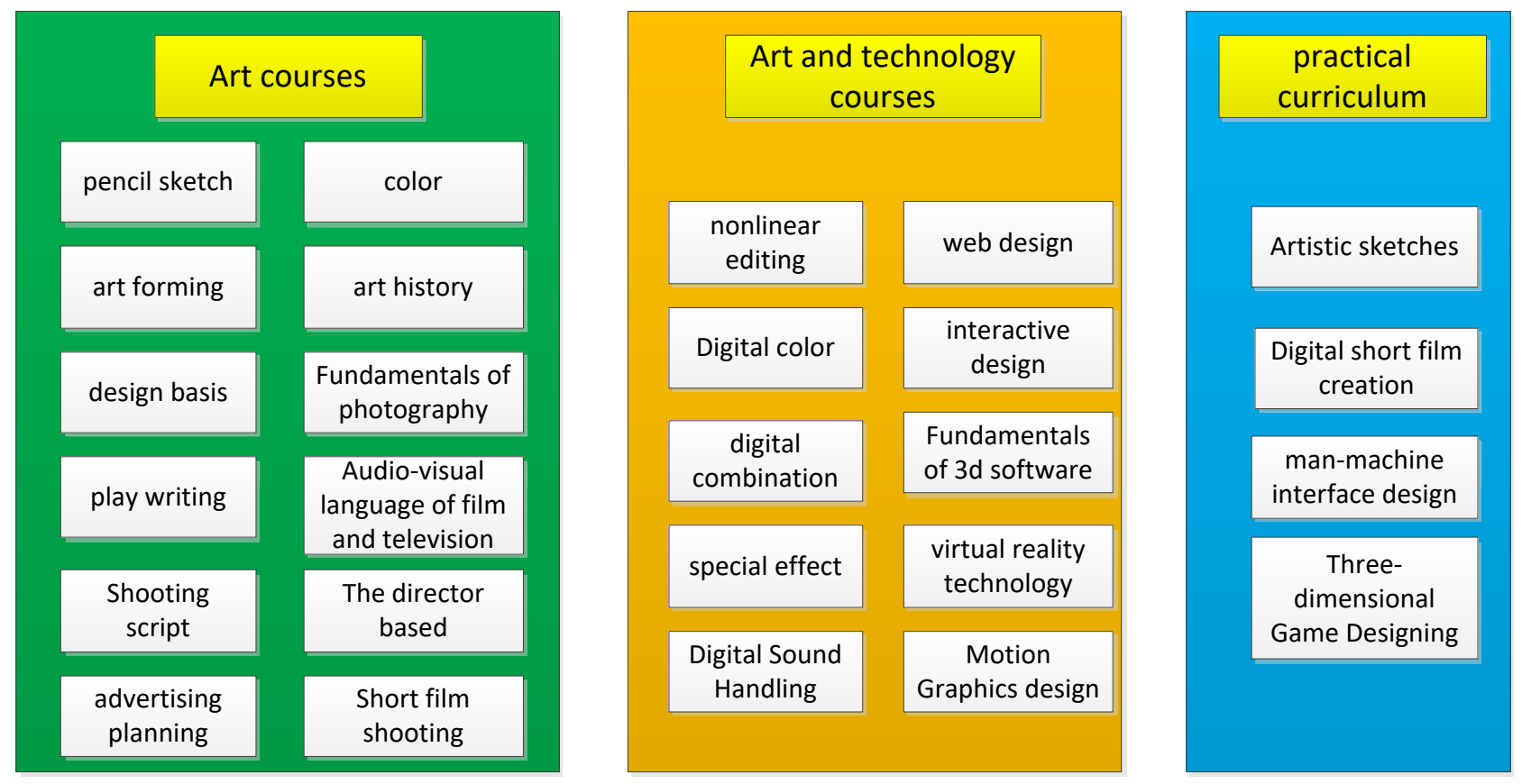

Fig. 2 Core courses of digital media art

It mainly includes:

(1) Art courses

The knowledge fields of art courses include sketch, color, composition, design basis, script creation, audio-visual language of film and television, director basis, etc. Art courses are designed to lay a good foundation for students' humanistic and artistic literacy, digital film and television field and solid artistic creation ability.

(2) Art and technology courses

The knowledge fields of technical courses cover three aspects: film and television special effects technology, 3d game technology and human-computer interaction. The curriculum of film and television in technical courses is designed to enable students to systematically master the technical application of digital media art, so that they can combine creativity and digital image technology to create digital image works. The courses of 3d game technology mainly enable students to have the pre-production technology of 3d game production, such as 3d scene modeling, character modeling and interaction with game engine. The course of human-computer interaction enables students to have the creative design ability of interactive product interface.

(3) Practical courses

Practical courses mainly include art sketching courses and the comprehensive application of three technical courses. Independent creative practice teaching can really improve students' creative comprehensive practical ability. During the four years of undergraduate study, arranging students to create a complete work independently in each academic year can cultivate students' solid technical ability, good innovation ability and comprehensive quality of solving problems. In practice class, students can be introduced to the latest developments of domestic and foreign science and technology development and display excellent digital media art works at home and abroad, hold excellent design works exhibition for students, actively organize students to participate in all kinds of competitions for college students above the provincial level, actively create an innovative atmosphere for students and cultivate their innovative consciousness. 


\section{Summary}

In recent years, digital media art major has been a hot topic of new majors in art colleges of various universities. The national standard for teaching quality of digital media major defines several mainstream directions for the application of digital media art major. However, colleges and universities should combine their traditional advantages to set up courses when constructing the curriculum system of digital media art major. Only good teachers can guarantee the teaching quality. This paper mainly discusses the course system of digital media art in colleges and universities, hoping to provide reference for other colleges and universities.

\section{Acknowledgement}

This paper is supported by grant from the Science Research Project of Wuhan Business University (Grant No. 2015KA011)-Research on the Current Situation and Development Strategy of Chinese 3D Animation Films.

\section{References}

[1] Zhigang Liu. The New Turn of Digital Media Art Major in the New Period and Its Strategies. Educational Theory and Practice. Vol. 38 (2018) No. 15, p. 20-21.

[2] Ping Gao, Xiaolan Zeng. Research on the Course System of Digital Media Art Major. Research on Design Art. Vol.8 No.3 2018, p. 51-55.

[3] Hui Yang,Jianhui Chi. Exploration and Reflection on the Cultivation of Digital Media Art Talents under the Background of Industry-Education Integration: A Case Study of Changzhou Institute of Information Technology. Educational Theory and Practice. 2015(36):p.21-23 .

[4] Jinghuang Hu. Reflections on the Course System Construction of Digital Media Art Major in Independent College. Journal of Shenzhen Polytechnic. 2017(4):p.61-65. 